\title{
Analisis Pengaruh Lingkungan Kerja, Kompensasi Dan Kepemimpinan Terhadap Efektivitas Kerja Karyawan
}

\author{
Sozanolo Waruwu \\ Dosen Fakultas Ekonomi Universitas Pamulang \\ Email :dosen01646@unpam.ac.id
}

\begin{abstract}
ABSTRAK
Penelitian ini bertujuan untuk mengetahui factor-faktor yang mempengaruhi Efektivitas kerja karyawan pada PT. Cipta Abadi Mandiri.Factor-faktor tersebut yaitu lingkungan kerja, kompensasi dan kepemimpinan. Meningkatnya kualitas lingkungan kerja dan karyawan yang memiliki kompensasi serta kepemimpinan yang baik akan memberikan dampak positif bagi organisasi, sehingga tujuan tercapai.

Pengujian hipotesis dilakukan dengan menyebar kuesioner sebanyak 96 karyawan PT Cipta Abadi Mandiri. Analisis yang digunakan yaitu uji validitas, uji reliabilitas, dan uji hipotesis, dan bantuan computer program SPSS versi 16 menggunakan analisis regresi linier berganda.

Dengan menggunakan metode analisis regresi berganda, dapat disimpulkan bahwa variable lingkumgan kerja $\left(\mathrm{X}_{1}\right)$ berpengaruh positif dan signifikan terhadap efektivitas kerja karyawan. Dengan nilai yang sebesar 12,99 (lebih besar dari $t_{\text {tabel }}$ 12,985) yang berarti bahwa lingkungan kerja memiliki pengaruh terhadap efektivitas kerja karyawan. Variabel kompensasi $\left(\mathrm{X}_{2}\right)$ berpengaruh positif dan terhadap efektivitas kerja karyawan. Dengan nilai hitung sebesar 12,808 (lebih besar dari $t_{\text {tabel }}$ ) yang berarti bahwa kompensasi memiliki pengaruh terhadap efektivitas kerja karyawan. Tabel kepemimpinan $\left(\mathrm{X}_{3}\right)$ berpengaruh positif dan signifikan terhadap efektivitas kerja karyawan. Dengan hitung sebesar 5,835 (lebih besar dari $t_{\text {tabel }}$ 1,985) yang berarti bahwa kepemimpinan memiliki pengaruh terhadap efektivitas kerja karyawan. Secara simultan ketiga variabel bebas berarti yaitu lingkungan kerja, kompensasi dan kepemimpinan berpengaruh positif dan signifikan terhadap efektivitas kerja karyawan dengan nilai Fhitung 63,47 (lebih besar dari $\mathrm{F}_{\text {table }} 3,09$ ), dapat disimpulkan bahwa lingkungan kerja, kompensasi dan kepemimpinan memiliki pengaruh signifikan terhadap efektivitas kerja karyawan PT Cipta Abadi Mandiri.
\end{abstract}

\section{Kunci : Lingkungan Kerja, Kompensasi dan Kepemimpinan, terhadap Efektivitas Kerja Karyawan.}




\section{PENDAHULUAN}

\section{Latar Belakang}

Pada Umumnya efektivitas sering dihubungkan dengan efisiensi dalam pencapaian tujuan organisasi. Padahal suatu tujuan atau saran telah dicapai sesuai dengan rencana dapat dikatakan efektif, tetapi belum tentu efisien. Walaupun terjadi suatu peningkatan efektivitas dalam suatu organisasi belum tentu itu efisien. Jelasnya, jika sasaran atau tujuan telah tercapai sesuai dengan yang direncanakan sebelumnya dapat dikatakan efektif. Jadi bila suatu pekerjaan itu tidak selesai sesuai waktu yang telah ditentukan, maka dapat dikatakan tidak efektif. Jadi bila suatu pekerjaan itu tidak selesai sesuai waktu yang telah ditentukan maka dapat dikatakan tidak efektif. Efektivitas merupakan gambaran tingkat keberhasilan atau keunggulan dalam mencapai sasaran yang telah ditetapkan dan adanya keterkaitan antara nilai-nilai bervariasi.

Efektivitas kerja pegawai yang baik secara langsung akan mempengaruhi kinerja lembaga dan untuk memperbaiki kinerja pegawai tentu merupakan suatu pekerjaan yang memakan waktu dan proses yang panjang. Selain dengan meningkatkan pengawasan dan pembinaan, juga dilakukan penilaian terhadap tingkat keberhasilan kinerja yang telah dilakukan oleh para pegawainya melalui peran pemimpin yang cakap mempimpin instansi tersebut.Untuk itu yang menarik untuk dikaji secara lebih seksama dan mendalam, khususnya kajian efektivitas kerja pegawai yang dipengaruhi oleh variabel kempemimpinan, variabel lingkungan kerja dan variabel kompensasi.

Instansi yang mempunyai lingkungan kerja yang baik dan nyaman akan memberikan motivasi bagi karyawannya untuk meningkatkan kinerjanya Selain itu kondisi kerja yang baik akan membantu mengurangi kejenuhan dan kelelahan, sehingga diharapkan dapat meningkatkan kinerja karyawan, Menurut Moekijat (2002:135).

Lingkungan kerja merupakan segala sesuatu yang ada disekitar pekerja dan dapat mempengaruhi dalam bekerja meliputi pengaturan penerangan, pengontrolan suara gaduh, pengaturan kebersihan tempat kerja dan pengaturan keamanan tempat kerja, Menurut Sukanto dan Indriyo (2000:151).

Pegawai di lingkungan PT.Cipta Abadi Mandiri Finance dalam rangka memberikan pelayanan terpercaya kepada masyarakat khususnya jasa keuangan menurut pengamatan penulis selama ini masih belum optimal. Hal ini berdampak pada penyelenggaraan organisasi kurang dapat terwujud secara baik. Pegawai sering mangkir atau tidak berada ditempat saat waktu efektif kerja, sehingga mengakibatkan kurang optimalnya penyelesaian tugas dan tanggung jawab yang harus diselesaikan. Kondisi ini nampaknya juga sering terjadi akibat kurangnya fungsi pengawasan oleh atasan pegawai yang bersangkutan. Selama kurun waktu 2014 sampai dengan 2015 jumlah pegawai yang tidak masuk kantor dikarenakan tidak ada keterangan (alpha) cenderung mengalami peningkatan, peningkatan tersebut berlangsung secara terus 
menerus setiap bulannya. Indikasi permasalahan di lapangan terletak pada fungsi pemimpin yang kurang tegas dan kurang melakukan evaluasi serta tidak efektifnya pemimpin memonitor setiap harinya. Selanjutnya faktor lainnya yaitu kondisi kantor yang kurang baik penataan ruangan serta kebisingan yang tinggi juga mengakibatkan karena kurang optimalnya tugas yang mereka terima sebagai pegawai administratif yang bersifat fasilitatif sesuai uraian tugas masing-masing pegawai maka tanggung jawab pegawai tidak dapat optimal, dan cenderung terhambat.

Menurut Lodge dan Derek (2003:104) menyebutkan perilaku pemimpin memiliki dampak signifikan terhadap sikap, perilaku dan kinerja karyawan. Efektivitas pemimpin dipengaruhi karakteristik bawahannya dan terkait dengan proses komunikasi yang terjadi antara pemimpin dan bawahan. Pimpinan dikatakan tidak berhasil apabila tidak dapat memotivasi, menggerakkan dan memuaskan karyawan pada suatu pekerjaan dan lingkungan tertentu.

Hasil penelitian Widyatmini dkk (2008:165) membuktikan bahwa kepemimpinan memiliki pengaruh yang sangat signifikan terahadap kinerja pegawai, hal ini menyimpulkan bahwa semakin baik kepemimpinan maka kinerja pegawai juga akan lebih baik.

Lingkungan kerja PT.Cipta Abadi Mandiri Finance merupakan suatu saran atau tempat yang sangat berperan dalam suatu organisasi menurut pengamatan penulis selama ini masih kurang kondusif. Biasanya organisasi hanya mengambil tindakan yang sangat sederhana dalam penanganan lingkungan kerja, yang mengakibatkan aspek-aspek tersebut berdampak pada psikologi pegawai, sehingga secara tak langsung akan menimbulkan hambatan-hambatan dalam pencapaian efektivitas kerja pegawai.

PT. Cipta Abadi Mandiri merupakan salah satu perusahaan yang bergerak di bidang penjualan kaca, aluminium,baja ringan dan juga pelayanan dalam pembuatan kebutuhan perkantoran. Penelitian ini memfokuskan pada perusahaan PT. Cipta Abadi Mandiri yang beroperasi di Jakarta barat. Oleh karena itu perusahaan pada PT. Cipta Abadi Mandiri sangat memperhatikan lingkungan kerja,kompensasi maupun kepemimpinan dalam perusahaan. Pada beberapa bulan terakhir PT. Cipta Abadi Mandiri mengalami beberapa kendala dalam menjalankan perusahaanya, diantaranya yang menggambarkan ketikdahadiran, tingkat keterlambatan serta tingkat kemajuan perusahaan.

Tabel 1.1

Data Ketikhadiran dari Tahun 2014-2015

\begin{tabular}{|c|c|c|c|c|}
\hline Tahun & $\begin{array}{l}\text { Jumlah } \\
\text { Karyawan }\end{array}$ & Ijin & Sakit & $\operatorname{lpa}^{A}$ \\
\hline $14^{20}$ & 86 & $1^{4}$ & $6^{4}$ & $05^{1}$ \\
\hline $15^{20}$ & 96 & $0^{8}$ & $2^{6}$ & $15^{1}$ \\
\hline
\end{tabular}

Berkaitan dengan uraian tersebut, maka menurut hemat penulis, PT.Cipta Abadi Mandiri Finance saat ini, pimpinan kurang respontif 
menyikapi permasalahan internenal organisasi sehingga menyebabkan permasalahan berkembang menjadi lebih besar. Efektivitas kerja karyawaan yang kurang kondusif sehingga karyawan kurang memperhatikan tentang tugas-tugas dan peran-peran yang harus diselesaikan, dimana dimana tugas pokok dan fungsi tidak dilaksanakan secara utuh. Karyawan kurang dapat memanfaatkan waktu, sarana dan prasarana yang tersedia, dilihat dari kenyataan banyaknya pegawai yang menggangur pada jam-jam kerja dan pemanfaatan sarana seperti computer, sarana mobilitas tidak dapat dilakukan secara optimal. Pemberian kompensasi yang dianggap masih jauh dari apa yang di harapkan sering membuat pekerjaan yang akan dilakukan tidak secara efesien bahkan kadang kala pekerjaan itu di lakukan karena terpaksa, meskipun tuntutan pekerjaan harus dilakukan secara professional.

kurang oleh karyawan terutama dalam tunjangan-tunjangan serta kompensasi dalam bentuk lainnya. Berkaitan keadaan di atas, maka untuk mengetahui hal tersebut lebih akurat, perlu dilakukan suatu penelitian yang lebih mendalam maka peneliti mengajukan judul :

"Pengaruh Lingkungan Kerja, Kompensasi dan Kemimpinan terhadap Efektivitas Kerja Pegawai pada PT.Cipta Abadi Mandiri Finance".

\section{Identifikasi Masalah}

Berdasarkan uraian sebelumnya, maka penulis mengidentifikasikan bahwa terdapat permasalahan permasalahan yang terkait dengan
Kepemimpinan, Lingkungan Kerjaan Pemberian Kompensasi serta pengaruhnya terhadap Efektivitas Kerja Pegawai pada PT. Cipta Abadi Mandiri sebagai berikut:

1. Menurunya tingkat kehadiran karyawan tiap Tahunnya di perusahaan PT. Cipta Abadi Mandiri

2. Sebagian karyawan memiliki hubungan yang kurang baik dengan pimpinan perusahaan

3. Rendahnya pemberian kompensasi kepada karyawan sehingga efektivitas kerja karyawan kurang maksimal

4. Lingkungan kerja yang yang kurang memadai sehingga banyak karyawan tidak mampu bekerja maksimal

5. Lingkungan kerja pegawai di lingkungan kerja saat ini nampaknya belum tertata guna mengingkatkan efektivitas kerja pegawai

6. Pemberian kompensasi pegawai di lingkungan kerja belum disesuaikan dengan pertumbuhan ekonomi sehingga efektivitas kerja Pegawai belum tercapai.

7. Kurangnya pembinaan dengan kemampuan profesional karyawan yang berada didalamnya sehingga membuat karywan tidak semngat dalam bekerja atau mengembangkan skill yang di milikinya.

\section{Pembatasan Masalah}

Permasalahan Efektivitas Kerja Pegawai pada PT. Cipta Abadi Mandiri Finance dipengaruhi berbagai faktor, baik yang terkait langsung maupun tidak langsung dengan tugas dalam pengembangan kompetensi sumber daya manusia. 
Namun penulis membatasi pada 3 (tiga) aspek yang mempengaruhi Efektivitas Kerja Pegawai pada yakni: Kepemimpinan, Lingkungan Kerja dan Pemberian Kompensasi terhadap efektivitas kerja karyawan.

\section{Perumusan Masalah}

Berdasarkan uraian - uraian yang telah dikemukakan, maka rumusan masalah penelitian ini adalah sebagai berikut:

1. Apakah lingkungan kerja berpengaruh positif dan signifikan terhadap efektivitas kerja karyawan?

2. Apakah Kompensasi berpengaruh positif dan signifikan terhadap efektivitas kerja karyawan?

3. Apakah Kepemimpinan berpengaruh positif dan signifikan terhadap efektivitas kerja karyawan?

4. Apakah lingkungan kerja, kompensasi dan kepemimpinan secara simultan berpengaruh positif dan signifikan terhadap efektivitas kerja karyawan

\section{Tujuan Penelitian}

Berdasarkan perumusan masalah penelitian tersebut, penelitian ini adalah untuk mendeskripsikan dan menganalisis:

1. Untuk mengetahui pengaruh kepemimpinan mempunyai pengaruh terhadap Efektivitas kerja pegawai pada PT. Cipta Abadi Mandiri Finance?

2. Untuk mengetahui pengaruh lingkungan kerja mempunyai pengaruh terhadap efektivitas kerja pegawai pada PT. Cipta Abadi Mandiri Finance?

3. Untuk mengetahui pengaruh pemberian

kompensasi mempunyai pengaruh terhadap efektivitas kerja pegawai pada PT. Cipta Abadi Mandiri Finance?

4. Untuk mengetahui pengaruh kepemimpinan, lingkungan kerja dan pemberian kompensasi secara simultan terhadap efektivitas kerja karyawan.

\section{TINJAUAN TEORITIK KERANGKA BERPIKIR DAN PENGAJUAN HIPOTESIS}

\section{Model Penelitian}

$\left(\mathrm{X}_{1}\right)=$ Lingkungan Kerja

$\left(\mathrm{X}_{2}\right)=$ Kompensasi

$\left(\mathrm{X}_{3}\right)=$ Kepemimpinan

(y) = Efektivitas Kerja

$>$ Ry1 = Hubungan secara parsial secara variabel $\mathrm{X}_{1}$ dan $\mathrm{y}$ menunjukkan besarnya pengaruh $\mathrm{X}_{1}$ terhadap y

$>\mathrm{X}_{2}=$ Hubungan secara parsial secara variabel $\mathrm{X}_{2}$ dan $\mathrm{y}$ menunjukkan besarnya pengaruh $\mathrm{X}_{2}$ terhadap y

$>\mathrm{X}_{3}=$ Hubungan secara parsial secara variabel $\mathrm{X}_{3}$ dan $\mathrm{y}$ menunjukkan besarnya pengaruh $\mathrm{X}_{3}$ terhadap y

$>\mathrm{Ry}_{123}=$ Hubungan secara menyeluruh variabel bebas dan y menunjukkan

besarnya pengaruh variabel bebas terhadap y.

\section{Hipotesis Penelitian}

Berdasarkan kerangka berpikir yang dikemukakan diatas, dapatlah 
di ajukan beberapa hipotesis penelitian, sebagian jawaban sementara terhadap masalah penelitian yang di rancang sebelumnya, sebagai berikut :

1. Diduga terdapat pengaruh positif lingkungan kerja terhadap efektivitas kerja karyawan pada PT. Cipta Abadi Mandiri Finance Tangerang

2. Diduga terdapat pengaruh positif kepemimpinan kerja terhadap efektivitas kerja karyawan pada PT. Cipta Abadi Mandiri Finance Tangerang

3. Diduga terdapat pengaruh positif kompensasi terhadap efektivitas kerja karyawan pada PT. Cipta Abadi Mandiri Finance Tangerang

4. Diduga terdapat pengaruh positif lingkungan kerja, kompensasi dan kepemimpinan secara bersamasama terhadap efektivitas kerja karyawan pada PT. Cipta Abadi Mandiri Finance Tangerang.

\section{METODOLOGI PENELITIAN}

Pada penyusunan proposal ini, peneliti menggunakan metode penelitian secara kuantitatif yang mana peneliti menanyakan ke beberapa orang yang di sebut responden, tentang keyakinan, pendapat,karateristik suatu obyek dalam hal ini pada perusahaan PT. Cipta Abadi Finance.

\section{HASIL DAN PEMBAHASAN}

\section{Deskripsi Obyek Penelitian}

PT. Cipta Harapan Jaya Finance merupakan perusahaan yang bergerak di bidang jasa pengiriman barang dan juga memberikan pinjaman tunai secara berkala.

\section{Gambaran Umum Responden}

1. Jenis kelamin

2. Status Karyawan

3. Usia Karyawan

4. Masa Kerja Karyawan

5. Pendidikan Karyawan

\section{Pengujian Persyaratan Analisis}

\section{a. Uji Instrumen}

Pengujian instrumen sangat penting, untuk mengetahui informasi kualitas instrumen yang dikembangkan apakah valid/ shahih atau tidak. Tahap pengujian ini meliputi uji validitas dan reabilitas. Uji validitas digunakan berkenan dengan ketetapan alat ukur terhadap konsep yang diukur sehingga benar - benar mengukur apa yang yang seharusnya diukur. Berkaitan dengan pengujian validitas instrumen menurut Riduwan ( 2004 : 109 - 110 ) menjelaskan bahwa validitas adalah suatu urusan yang menunjukkan tingkat kendala atau kelebihan suatu alat ukur. Alat ukur yang kurang valid berarti memeiliki validitas rendah. Demikian pulu sebaliknnya. Uji validitas dilakukan dengan membandingkan nilai $r$ hitung dengan nilai $r$ tabel, pada signifikasi sebesar 0,05 (5\%) dan derajat kebebasan $(\mathrm{dk}=96=93)$ sebesar 0,2017.

Uji reabilitas dilakukan untuk mandapatkan tingkat ketetapan (keterandalan atau keajegan) atau pengumpul data (instrumen) yang digunakan. Tingkat reliabilitas suatu konstruk / variabel penelitian dapat dilihat dari hasil statistik Ccronbach Alpha $(\alpha)$ Suatu variabel dikatakan reliable 
jika memberikan nilai cronbach alpha> 0,60 (Ghozali, $2005: 41-$ 42). Berikut tabel hasil uji reliabilitas tiap variable

\section{b. Uji Heteroskedastisitas Data}

Uji Heteroskedastisitas dengan uji spearman Rho. Uji Spearman dilakukan dengan cara mengkorelasikan nilai Unstandardized residual dengan masing-masing variabel independen $\left(X_{1} X_{2}\right.$ dan $\left.X_{3}\right)$, hipotesis pengujian yaitu :

Ho : tidak ada gejala heteroskedastisitas

Ho : ada gejala heteroskedastisitas

Ho : di terima apabila nilai $\mathrm{P}$ value atau signifikan $>0,05$.

\section{c. Pengujian penelitian}

Analisis Hipotesis korelasional antara variabel

$\mathrm{O}>$ - 0,25: Korelasi sangat lemah

$\mathrm{O}>-0,25-0,5$ : Korelasi sangat cukup

$\mathrm{O}>-0,25-0,75 \quad$ : $\quad$ Korelasi kuat

$\mathrm{O}>-0,25-1$ : Korelasi sangat kuat

a. Korelasi antara lingkungan kerja dengan efektivitas kerja

Menggunakan uji, signifikan jika sig > 0,05 maka Ho diterima, jika sig $<0,05$ maka H1 diterima. Diketahui nilai signifikan $=0.000$ $<0,05$, maka H1 diterima " ada hubungan korelasi sebesar 0.802 bersifat sangat kuat dan searah (positif), korelasi dua variabel bersifat signifikan karena angka signifikasinya sebesar $0.000<$ 0,05 . b. Korelasi antara kompensasi dengan efektivitas kerja

Korelasi sebesar 0.797 bersifat sangat kuat dan searah ( positif), korelasi dua variabel bersifat signifikan karena signifikannya sebesar $0.000<0,05$.

c. Korelasi antara kepemimpinan dengan efektivitas kerja

Korelasi sebesar 0.516 bersifat sangat kuat dan searah ( positif), korelasi dua variabel bersifat signifikan karena signifikannya sebesar $0.000<0,05$.

d. Pengaruh lingkungan kerja, kompensasi, dan kepemimpinan terhadap efektvitas kerja karyawan.

Persamaan pengaruh lingkungan kerja, kompensasi, dan kepemimpinan terhadap efektvitas kerja karyawan dapat diuraikan sebagai berikut :

$>$ ryl $(0,802)=$ Koefisien korelasi ry1 sebesar 0,802 . Angka ini menggambarkan bahwa pengaruh lingkungan kerja terhadap efektvitas kerja karyawan adalah positif dalam kategori sangat kuat.

ry2 $(0,797)=$ Koefisien korelasi ry2 sebesar 0,797. Angka ini menggambarkan bahwa pengaruh kepemimpinan terhadap efektvitas karyawan adalah positif dalam kategori sangat kuat.

ry3 $(0,516)=$ Koefisien korelasi ry3 sebesar 0,516. Angka ini menggambarkan bahwa pengaruh kompensasi terhadap efektivitas kerja 
karyawan adalah positif dalam kategori kuat.

Ry1,2,3(0,674) = lingkungan kerja, kompensasi dan kepemimpinan memiliki pengaruh terhadap efektivitas kerja karyawan secara bersama - samasebesar $67 . \%$. $(0,326)=$ faktor lain diluar dari lingkungan kerja, kompensasi dan kepemimpinan memiliki pengaruh terhadap efektivitas kerja karyawan sebesar $32.6 \%(100 \%-67.4 \%)$.

\section{PENUTUP}

\section{Kesimpulan}

Berdasarkan hasil analisasi dan pembahasan sebagaimana yang telah diuraikan pada bab terdahulu, maka dapat di tarik beberapa kesimpulan sebagai berikut : Lingkungan Kerja

Berdasarkan hasil pengolahan data bahwa ada pengaruh antara lingkungan kerja perusaan PT. Cipta abadi mandiri kabupaten tangerang, dengan hasil yang diperoleh persamaan regresi $\mathrm{Y}=25.765+$ $0,517 \mathrm{X} 1$ dimana apabila variabel lingkungan kerja $\left(\mathrm{X}_{1}\right)$ terjadi peningkatan 1 point maka efektivitas kerja ( $\mathrm{Y}$ ) akan mengalami peningkatan sebesar 0,517. Koefisien determinasi lingkungan kerja adalah sebesar $8,5 \%$. Diketahui bahwa nilai $\mathrm{t}$ hitung untuk efektivitas kerja adalah 1,985 dan diperoleh distribusi normal $t_{\text {tabel }}$ adalah 12,99 berarti kondisi tersebut menunjukkan bahwa Ho ditolak pada tingkat kesalahan 5\% dan Ha diterima pada tingkat keyakinan $95 \%$.

1. Kompensasi

Berdasarkan hasil pengolahan data bahwa ada pengaruh antara kompensasi kerja perusaan PT.
Cipta abadi mandiri kabupaten tangerang, dengan hasil yang diperoleh persamaan regresi $\mathrm{Y}=$ $14.742+0,451$ X2. dimana apabila variabel lingkungan kerja $\left(\mathrm{X}_{2}\right)$ terjadi peningkatan 1 point maka efektivitas kerja ( $\mathrm{Y}$ ) akan mengalami peningkatan sebesar 0,451. Koefisien determinasi kompensasi adalah sebesar 6,5\%. Diketahui bahwa nilai $\mathrm{t}$ hitung untuk efektivitas kerja adalah 1,985 dan diperoleh distribusi normal $t_{\text {tabel }}$ adalah 12,808 berarti kondisi tersebut menunjukkan bahwa Ho ditolak pada tingkat kesalahan 5\% dan $\mathrm{Ha}$ diterima pada tingkat keyakinan $95 \%$.

2. Kepemimpinan

Berdasarkan hasil pengolahan data bahwa ada pengaruh antara kepemimpinan kerja perusaan PT. Cipta abadi mandiri kabupaten tangerang, dengan hasil yang diperoleh persamaan regresiY $=35.143+0,487 \mathrm{X} 3$. Dimana apabila variabel kepemimpinan $\left(\mathrm{X}_{3}\right)$ terjadi peningkatan 1 point maka efektivitas kerja ( $\mathrm{Y}$ ) akan mengalami peningkatan sebesar 0,487 . Koefisien determinasi kompensasi adalah sebesar 6,5 $\%$. Diketahui bahwa nilai $\mathrm{t}$ hitung untuk efektivitas kerja adalah 1,985 dan diperoleh distribusi normal $t_{\text {tabel }}$ adalah 5.835 berarti kondisi tersebut menunjukkan bahwa Ho ditolak pada tingkat kesalahan 5\% dan Ha diterima pada tingkat keyakinan $95 \%$.

3. Efektivitas kerja karyawan

$r_{y 1,2,3}$ sebesar 0,764, angka ini menggambarkan bahwa 
lingkungan kerja memiliki pengaruh positif dalam kategori kerja kuat terhadap efektivitas kerja karyawan secara bersama sama sebesar $67.4 \%$ dan 0,326 angka ini menggambarkan bahwa faktor lain diluar dari lingkungan kerja, kompensasi dan kepemimpinan memiliki pengaruh terhadap efektivitas kerja karyawan sebesar $32.6 \%$ ( $100 \%-67.4 \%$ ).

Dengan demikian dapat diambil kesimpulan bahwa, lingkungan kerja, kompensasi dan kepemimpinan secara simultan berpengaruh positif terhaap efektivitas kerja karyawan.

\section{DAFTAR PUSTAKA}

Ahmad Tohardi, (2002), Pemahaman

Praktis Manajemen Sumber Daya Manusia, UniversitasTanjung Pura, MandarMaju, Bandung.

Andi, Supangat. (2007). Statistik :Dalam Kajian Deskriptif, Inferensi, dan 14 Nonparametrik. Jakarta : Kencana.

Anwar Prabu Mangkunegara, 2001, Manajemen Sumber Daya Manusia Perusahaan; Bandung : PT. Remaja Rosda Karya.

Agus Dharma 2000, Manajemen Prestasi Kerja, Jakarta: Rajawali Pers.
Arep, Ishak dan Hendri Tanjung. 2003. Manajemen Sumber Daya Manusia. Jakarta: Universitas Trisakti.

Arikunto, Suharsimi. 1998. Prosedur Penelitian Suatu Pendekatan Praktik. Edisi Revisi. Cetakan Kesembilan. Rineka Cipta. Jakarta.

Assauri, Sofjan, "Manajemen Produksi dan Operasi Edisi Revisi 2004", Lembaga Penerbit FE-UI, Jakarta, 2004

B. Siswanto Sastrohadiwiryo, DR, (2003), Manajemen Tenaga Kerja Indonesia, edisi 2, PT. Bumu Aksara, Jakarta

Colquit, LePine, Wesson, 2009, Organizational Behavior Improving Performance and Commitmen in The Workplace, McGraw Hill International Edition

Daft, Richard L. 2003. Manajemen Sumber Daya Manusia. Jakarta : PenerbitErlangga.

Dessler, Garry. (2011). Manajemen Sumber Daya Manusia. Penerbit Indeks. Jakarta

Flippo, Edwin B. 1994. Manajemen Personalia : Edisi Keenam, Jilid 1. Jakarta : Erlangga

Ghozali, Imam, 2005. Aplikasi Analisis Multivariate dengan Program SPSS,Semarang : Penerbit Universitas Diponegoro. 